\title{
A fájdalmas beavatkozások száma és a fájdalomcsillapítás módozatai egy hazai neonatalis intenzív centrumban
}

\author{
Ivancsó Johanna dr. - Fejes Melinda dr. - Fürjész Dóra dr. - Kelen Mária dr. \\ Megyeri Tímea dr. - Váradi Katalin dr. - Szúcs Ildikó dr. \\ Borsod-Abaúj-Zemplén Megyei Központi Kórház és Egyetemi Oktatókórház, Újszülött Intenzív Osztály, Miskolc
}

Bevezetés: A neonatalis intenzív centrumokban kezelt betegek naponta számos fájdalmas beavatkozáson eshetnek át. A kezeletlen fájdalom következményeinek ismerete ellenére, fájdalmuk csillapítása még messze nem ideális.

Célkitüzés: Obszervációs tanulmányunk célja az osztályunkon kezelt koraszülötteket és beteg újszülötteket ért fájdalmas beavatkozások gyakoriságának és természetének meghatározása volt. Vizsgáltuk a procedurális fájdalom esetén alkalmazott gyógyszeres és nonfarmakológiai fájdalomcsillapítók használatát, valamint a beavatkozások számát és a fájdalomcsillapítás alkalmazását befolyásoló tényezőket.

Módszerek: A vizsgálatba az osztályunkon 2019. 09. 01. és 2019. 12. 31. között kezelt betegeket vontuk be. Prospektív adatgyújtést végeztünk a hospitalizáció első 14 napján, egy erre a célra kialakított kérdőíven, amelyet az egészségügyi személyzet valós időben töltött ki.

Eredmények: Kutatásunkba 143 gyermeket tudtunk bevonni. A vizsgálati időszak alatt 43-féle fájdalmas beavatkozás történt, összesen 13314 alkalommal, amiből 12953 első, 361 többszöri kísérlet volt. Gyermekenként átlagosan 93,1 beavatkozást végeztünk a hospitalizáció első 2 hetében, ami átlagosan 8,2 fájdalmas procedúrát jelentett naponta és gyermekenként. Fájdalomcsillapítás összesen 4190 alkalommal, a beavatkozások 31,5\%-ában történt. Ennek 55,5\%-a folyamatos gyógyszeres, 40,7\%-a nem gyógyszeres, 2,5\%-a alkalmi gyógyszeres, 1,3\%-a kombinált terápia volt. A legkisebb születési súlyú, legrövidebb gestatiós időre született és a lélegeztetett koraszülöttek szenvedték el a legtöbb fájdalmas beavatkozást.

Következtetés: Betegeink nagyszámú fájdalmas beavatkozáson esnek át, és ezek nagyobb részénél nem történik fájdalomcsillapítás. A beavatkozások tervezésével, összehangolásával, a gyógyszeres és nem gyógyszeres fájdalomcsillapítás kiterjedtebb alkalmazásával jobb fájdalommenedzsment lenne elérhető.

Orv Hetil. 2021; 162(48): 1931-1939.

Kulcsszavak: procedurális fájdalom, fájdalomcsillapítás, neonatalis intenzív centrum, újszülött

\section{Number of painful procedures and pain management in a neonatal intensive care unit}

Introduction: Preterm infants and sick neonates treated in neonatal intensive care units may undergo numerous painful interventions. Despite rapidly growing knowledge about consequences of untreated pain, pain management of neonates is far from ideal.

Objective: To determine the frequency and nature of painful procedures and corresponding analgesic therapies in neonates treated in a neonatal intensive care unit of a university teaching hospital in Hungary.

Methods: A prospective observational study was performed between September and December 2019. We collected data of all painful procedures, pharmacological and non-pharmacological analgesic therapy performed on neonates during the first 14 days of hospitalization. For data collection, we used a questionnaire designed for this purpose, which was completed in real time by the medical staff.

Results: 143 children were enrolled. 43 types of painful interventions were performed, a total of 13,314 times, of which 12,953 were the first, 361 multiple attempts. Each neonate was subjected to a mean of 93.1 interventions in the first 2 weeks of hospitalization, representing an average of 8.2 painful procedures per day per child. Pain relief was performed a total of 4190 times, in $31.5 \%$ of the interventions. Of this, $55.5 \%$ were continuous pharmacological, $40.7 \%$ non-pharmacological, $2.5 \%$ occasional drug, and $1.3 \%$ combination therapy. Ventilated neonates and preterm infants with shorter gestational age and lower birth weight had the most painful procedures. 
Conclusion: Patients treated in our unit undergo a large number of painful interventions, most of which are not accompanied by analgesia. Increased efforts are needed to promote our better pain management.

Keywords: procedural pain, analgesia, neonatal intensive care unit, neonate

Ivancsó J, Fejes M, Fürjész D, Kelen M, Megyeri T, Váradi K, Szűcs I. [Number of painful procedures and pain management in a neonatal intensive care unit]. Orv Hetil. 2021; 162(48): 1931-1939.

(Beérkezett: 2021. április 12.; elfogadva: 2021. május 16.)

\section{Rövidítések}

CVC = centrális vénás kanül; EKG = elektrokardiogram; IQR $=$ (interquartile range) interkvartilis tartomány; $\mathrm{NIC}=$ neonatalis intenzív centrum, $\mathrm{SD}=$ standard deviáció

Az utóbbi évtizedekben a neonatológiai ellátás fejlődésének hatására javultak a neonatalis intenzív centrumokban (NIC) kezelt betegek életben maradásának esélyei [1]. Egyre több extrém éretlen koraszülöttet és súlyos beteg újszülöttet kezelnek, ellátásuk pedig szükségszerúen egyre több fájdalmas beavatkozással is jár. A fájdalomcsillapításhoz való hozzájutás kortól független alapvető emberi jog [2]. Mégis megdöbbentően hosszú időnek kellett eltelnie ahhoz, hogy az orvostudomány felismerje: az újszülöttek, koraszülöttek is éreznek fájdalmat [3]. Az 1980-as évek óta drámai változás következett be az újszülöttek fájdalomérzékelésével kapcsolatos ismereteinkben. Vizsgálatok bizonyították, hogy a receptorok, a perifériás idegek, az agykéreg és a neuroendokrin rendszer fejlettsége már a legkisebb koraszülötteket is képessé teszi a fájdalom érzékelésére [4-6]. A leszálló cerebrospinalis gátlópályák fejletlensége miatt ugyanakkor az újszülöttek és a koraszülöttek kevésbé tudják csökkenteni vagy gátolni a nociceptiót, így érzékenyebbek a fájdalomra, mint a felnőttek [7].

A fájdalomnak nemcsak azonnali, de hosszú távú hatásai is ismertek. Az ismétlődő, kezeletlen fájdalom a központi idegrendszer fejlődésének kritikus szakaszában végleges változásokat idéz elő a fájdalomvezetésben, a neuroendokrin funkciókban és a neurológiai fejlődésben. Megváltoztatja a fájdalomküszöböt, a stresszválaszt, a kognitív funkciókat, a viselkedést, a figyelmet, a tanulási képességeket [8-14]. Ezért a fájdalomcsillapítás több, mint humanitárius és etikai kötelesség.

A neonatalis fájdalom rövid és hosszú távú káros hatásainak felismerése vezetett számos nemzeti és nemzetközi fájdalomkezelési irányelv elkészítéséhez [15-18]. A fájdalomcsillapítás ezen rendkívül érzékeny populáció minőségi ellátásának egyik alappillérévé vált [19]. A rohamosan növekvő ismeretanyag ellenére azonban tanulmányok igazolják, hogy a koraszülöttosztályokon alkalmazott fájdalomcsillapítás még messze nem ideális. A fájdalmas eljárások jelentős része a mai napig megfelelő analgesia nélkül történik [20-23].
A fájdalom kezelése nemcsak a fájdalomcsillapítási módszerek alkalmazását jelenti, hanem a fájdalom észlelését, mértékének becslését és a beavatkozások számának minimalizálását is. Ahhoz viszont, hogy ezen eljárások számát csökkenteni tudjuk, pontos ismeretekkel kell rendelkeznünk azok epidemiológiájáról. Ezért a kutatás elsődleges célja a Borsod-Abaúj-Zemplén Megyei Központi Kórház Újszülött Intenzív Osztályán kezelt koraszülötteket és beteg újszülötteket ért fájdalmas beavatkozások gyakoriságának és természetének a meghatározása volt. A fájdalomcsillapító szerek mellékhatásaitól, a gyógyszertoleranciától és -dependenciától való félelem, a koraszülöttek esetében a farmakokinetikai, farmakodinámiás és az adagolásra vonatkozó adatok gyakori hiánya korlátozhatja a fájdalomcsillapítók használatát [24]. Ezért a másodlagos célkitǔzés a fájdalmas beavatkozások esetén alkalmazott fájdalomcsillapítók használatának, valamint a fájdalomcsillapítást és a beavatkozások számát befolyásoló tényezőknek a vizsgálata volt.

\section{Módszerek}

A vizsgálatba bevontunk minden, a Borsod-AbaújZemplén Megyei Központi Kórház és Egyetemi Oktatókórház Újszülött Intenzív Osztályán 2019. 09. 01. és 2019. 12. 31. között kezelt, újonnan felvett koraszülöttet és beteg újszülöttet. Kizárási kritérium a felvételt követő 24 órán belüli elbocsátás vagy halál volt. Prospektív adatgyưjitést végeztünk minden, fájdalmat okozó beavatkozásról, a sikertelen kísérletekrôl és a beavatkozáshoz kapcsolódó fájdalomcsillapítás módjáról. A vizsgálat a betegek kezelésének első 14 napján történt. Az adatokat egy erre a célra kialakított kérdőíven rögzítettük. Ezt az egészségügyi személyzet valós időben töltötte ki. A kérdőívre kerülő fájdalmas beavatkozásokat korábbi, hasonló módszerrel végzett vizsgálatok átnézésével határoztuk meg [24-30]. Ezek alapján 37 fájdalmas beavatkozást soroltunk fel. Az ápolószemélyzet bármilyen egyéb, a listán nem szereplő, de fájdalmasnak ítélt eljárást is feljegyezhetett. A vizsgálat megkezdése előtt az adatrögzítésben részt vevő orvosoknak és nővéreknek oktatást tartottunk a kérdőív használatáról. A rögzített adatokat minden nap összesítettük, majd duplán ellenőriztük, a vizsgálat pontosságának fokozása érdekében. Lejegyez- 
tük a betegek általános jellemzőit (többek között a nemüket, születési súlyukat, gestatiós korukat), a légzéstámogatás módját, időtartamát. A beavatkozásokat naptári napokra számoltuk, az első és utolsó - általában 24 óránál rövidebb - napra vonatkozóan korrekciót nem végeztünk. Ha a beteg ápolása két hétnél rövidebb ideig tartott, az adatgyuujjtést az elbocsátásig végeztük. Nappal történtnek számoltuk a beavatkozást, ha az reggel 6 és este 18 óra közötti volt.

\section{Statisztikai analizis}

A statisztikai számításokat SPSS Statistics Version 26 szoftverrel (IBM Corporation, Armonk, NY, USA) végeztük. A betegek általános jellemzőit, a fájdalmas beavatkozások számát és a fájdalomcsillapítás alkalmazásának előfordulását deskriptív statisztikai módszerekkel vizsgáltuk (százalék, átlag, szórás, medián, terjedelem, interkvartilis tartomány [IQR]). A beavatkozások végzésének és a fájdalomcsillapítás használatának a betegek általános jellemzőivel való összefüggését Mann-Whitney U-, illetve Kruskal-Wallis-teszttel mértük. Statisztikailag szignifikánsnak a p<0,05 értéket határoztuk meg.

\section{Eredmények}

A vizsgálatba 143 gyermeket vontunk be. Általános jellemzőiket az 1. és 2. táblázatban foglaltuk össze. Gestatiós koruk a 23. és 41. hét között volt, az átlagos gestatiós idő 36 hét (SD: 3,9) volt. 24 koraszülött (17\%) a 32. gestatiós hét előtt, 18 beteg (13\%) 1500 gramm alatti súllyal született. Az átlagos ápolási idő 18 nap (SD: 15,5) volt. A páciensek kezelése a vizsgálati időszak alatt összesen 1624 betegnapot jelentett. A gyermekek 48\%-a császármetszéssel jött világra. 6 betegnek $(4 \%)$ volt szüksége mútétre. Légzéstámogatást a betegek $42 \%$-a igényelt. A vizsgált időszak alatt $1(0,7 \%)$ extrém éretlen koraszülött halt meg.

1. táblázat |A vizsgált betegek $(\mathrm{n}=143)$ megoszlása gestatiós kor és születési súly szerint

\begin{tabular}{cccc}
\hline & Betegszám $(\%)$ & Átlag $(\mathrm{SD})$ & Tartomány \\
\hline Gestatiós kor (hét) & & $36(3,9)$ & $23-41$ \\
\hline $23-28$. & $9(6,3)$ & & \\
$29-32$. & $15(10,5)$ & & \\
$33-36$. & $36(25,2)$ & & \\
37-41. & $83(58,0)$ & & \\
\hline Születési súly (g) & & & \\
\hline$\leq 1000$ & $9(6,3)$ & & \\
$1001-1500$ & $9(6,3)$ & & \\
$1501-2500$ & $46(32,2)$ & & \\
$>2500$ & $79(55,2)$ & & \\
\hline
\end{tabular}

SD = standard deviáció
2. táblázat $\mid$ A terhesség, születés, lélegeztetés, ápolás legjellemzőbb demog ráfiai adatai a vizsgálatban részt vevő betegek esetében

\begin{tabular}{|c|c|c|c|}
\hline & Betegszám (\%) & Átlag (SD) & Tartomány \\
\hline Császármetszés & $69(48,2)$ & & \\
\hline Gondozott terhesség & $109(76,2)$ & & \\
\hline IUGR & $34(23,7)$ & & \\
\hline Fiú & $80(55,9)$ & & \\
\hline Kor a felvételkor (h) & & $14,1(22,6)$ & $0,1-100$ \\
\hline Apgar, 1 perces & & $7,9(2,0)$ & $1-10$ \\
\hline Apgar, 5 perces & & $8,8(1,5)$ & $2-10$ \\
\hline Ápolási idő (nap) & & $18,3(15,5)$ & $4-104$ \\
\hline $\begin{array}{l}14 \text { napnál hosszabban } \\
\text { ápolt }\end{array}$ & $58(40,5)$ & & \\
\hline Meghalt & $1(0,7)$ & & \\
\hline Lélegeztetett & $61(42,6)$ & & \\
\hline $\begin{array}{l}\text { Csak konvencionális/ } \\
\text { HFO-lélegeztetés }\end{array}$ & $7(4,9)$ & & \\
\hline Csak noninvazív lélegeztetés & $37(25,9)$ & & \\
\hline $\begin{array}{l}\text { Konvencionális + } \\
\text { noninvazív lélegeztetés }\end{array}$ & $17(11,8)$ & & \\
\hline Mütét a vizsgált időszakban & $6(4,2)$ & & \\
\hline
\end{tabular}

$\mathrm{h}=$ óra; $\mathrm{HFO}=$ nagy frekvenciájú oszcillációs; IUGR = intrauterin növekedési visszamaradottság; $\mathrm{SD}=$ standard deviáció

\section{Fájdalmas beavatkozások}

A kérdőíven szereplő 37 beavatkozás mellé az ápolószemélyzet még 6-ot jegyzett fel. Így az 1624 betegnap alatt 43-féle fájdalmas beavatkozás történt, összesen 13314 alkalommal. Ezek a következók voltak: gyomorszonda levezetése és eltávolítása, ragasztószalag eltávolítása, sarok-, ujjbegy-, véna- és branülszúrás, perifériáról centrális helyzetbe vezetett kanül (CVC) behelyezése és eltávolítása, branül eltávolítása, vena umbilicalis kanül behelyezése, kiöltése és eltávolítása, subcutan és intramuscularis injekció adása, intubálás, extubálás, nasalis, trachealis, oralis szívás, orrkanül behelyezése, vizeletgyűjtő zsák eltávolítása, garatváladék-vétel, szemészeti vizsgálat, sebkezelés, varratszedés, kötéscsere, EKGelektróda eltávolítása, hólyagnyomás, agresszív stimulálás, mellkasi fizioterápia, beöntés, hólyagkatéter behelyezése és eltávolítása, mellkasi drén behelyezése és eltávolítása, bronchoalveolaris lavage, bőrbiopszia, Penrose drén behelyezése és eltávolítása, fiberoszkópos vizsgálat, lumbálpunkció, necrectomia. Ezekből 12953 első, 361 (2,7\%) többszöri kísérlet volt. A sikertelen próbálkozások a sarokszúrások 3\%-ában, a véna- és branülszúrások 14 és 35\%-ában, az intubálások 7\%-ában fordultak elő. Nappal 7747 (58\%), éjszaka 5567 (42\%) beavatkozás történt. Gyermekenként átlagosan 93,1 beavatkozást (SD 78,7) végeztünk a kórházi kezelés első 2 hetében (tartomány: 13-307), ami átlagosan 8,2 (SD 7,83 ) fájdalmas eljárást jelentett naponta és gyermeken- 
3. táblázat | Az összes és ebből a 10 leggyakoribb fájdalmas beavatkozás formája, gyakorisága és előfordulása az érintett betegek arányában

\begin{tabular}{l|c|c|c|c|c|c}
\hline Beavatkozások száma & \multicolumn{4}{c}{ Gyakoriság } & \multicolumn{2}{c}{ Betegek } \\
\hline & száma & Napi átlag $(\mathrm{SD})$ & Betegátlag $(\mathrm{SD})$ & Nap/beteg átlag $(\mathrm{SD})$ & száma & $\%$-a \\
\hline Összes beavatkozás & 13314 & $951(447,80)$ & $93,1(78,76)$ & $8,2(7,83)$ & 143 & 100 \\
\hline Gyomorszonda levezetése & 3427 & $244,79(97,19)$ & $23,97(28,39)$ & $1,71(2,02)$ & 105 & 73,42 \\
\hline Gyomorszonda eltávolítása & 3420 & $244,29(97,07)$ & $23,92(28,33)$ & $1,71(2,02)$ & 105 & 73,42 \\
\hline Ragasztó eltávolítása & 1059 & $75,64(50,40)$ & $7,41(4,68)$ & $0,53(0,33)$ & 142 & 99,30 \\
\hline Sarokszúrás & 1005 & $71,79(59,10)$ & $7,03(6,67)$ & $0,50(0,47)$ & 143 & 100 \\
\hline Vérvétel-vénaszúrás & 640 & $45,71(37,05)$ & $4,48(2,47)$ & $0,32(0,17)$ & 143 & 100 \\
\hline Nasalis szívás & 611 & $43,64(13,50)$ & $4,27(9,45)$ & $0,31(0,67)$ & 52 & 36,36 \\
\hline Branülszúrás & 407 & $29,07(23,75)$ & $2,85(2,51)$ & $0,20(0,17)$ & 114 & 79,72 \\
\hline Orrkanül behelyezése & 398 & $28,43(29,44)$ & $2,78(4,63)$ & $0,20(0,33)$ & 54 & 37.76 \\
\hline Branül eltávolítása & 349 & $24,93(14,77)$ & $2,44(2,28)$ & $0,17(0,16)$ & 108 & 75,52 \\
\hline Tubusszívás & 313 & $22,36(7,07)$ & $2,19(6,72)$ & $0,16(0,48)$ & 24 & 16,78 \\
\hline
\end{tabular}

$\mathrm{SD}=$ standard deviáció

ként (tartomány: 0-36). A 43-féle beavatkozásból a 10 leggyakoribb a gyomorszonda levezetése és eltávolítása, a ragasztószalag eltávolítása, a sarok-, véna- és branülszúrás, a nasalis és trachealis szívások, az orrkanül behelyezése és a branül eltávolítása volt (3. táblázat). Ezek közül véna- és sarokszúrás minden vizsgált gyermeknél, ragasztószalag-eltávolítás a 99\%-uknál, perifériás vénabiztosítás a $80 \%$-uknál történt. A legtöbb fájdalmas beavatkozást az első 2 ápolási napon végeztük (1. ábra).

A beavatkozások számát befolyásoló tényezőket vizsgálva (5. táblázat): mind azok napi átlagszámát, mind az első 14 nap alatt elszenvedett összes beavatkozást tekintve azt találjuk, hogy mindkét esetben az 1500 gramm alatti születési súlyú és a 32. gestatiós hétnél fiatalabb koraszülöttek szenvedték el a legtöbb fájdalmat.
A gestatiós idő rövidülésével $(\mathrm{p}<0,001)$ és a születési súly csökkenésével $(\mathrm{p}<0,001)$ szignifikánsan nőtt a fájdalmas beavatkozások száma. Szintén szignifikánsan több beavatkozáson estek át a lélegeztetett gyermekek $(\mathrm{p}<0,001)$.

\section{Fájdalomcsillapitás}

Fájdalomcsillapítás összesen 4190 alkalommal, a beavatkozások 31,5\%-ában történt. Ennek 55,5\%-a folyamatos gyógyszeres, 40,7\%-a nem gyógyszeres, $2,5 \%$-a alkalmi gyógyszeres kezelés, 1,3\%-a gyógyszeres és nem gyógyszeres terápia kombinációja volt. Összesen 140 gyermek $(98 \%)$ részesült valamilyen fájdalomcsillapításban. Hárman nem kaptak semmilyen analgetikus kezelést. Ők

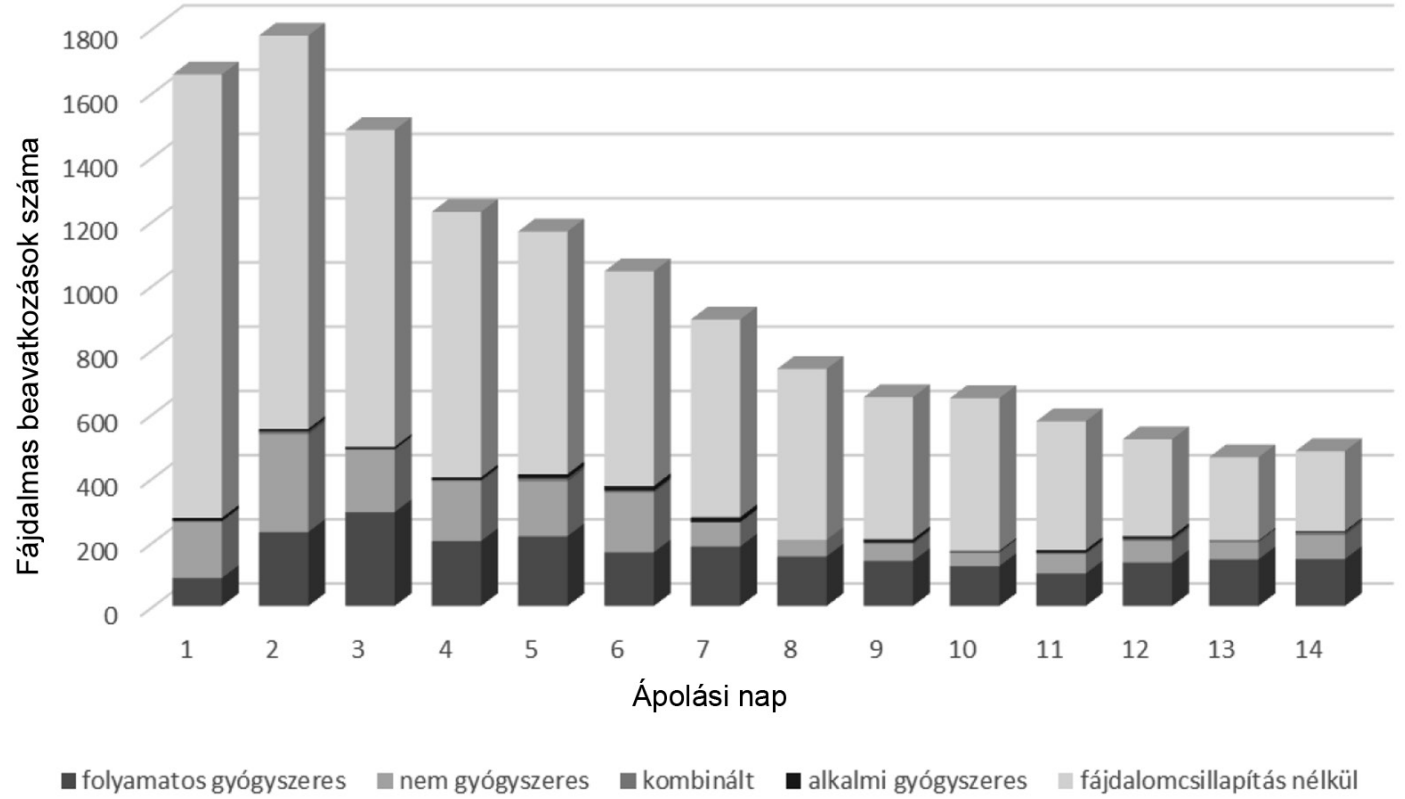

1. ábra |A fájdalmas beavatkozások összes száma és a kapcsolódó fájdalomcsillapítás formái a hospitalizáció elsó 14 napján a vizsgálatba bevont 143 gyermeknél 
Az összes és a 10 leggyakoribb fájdalmas beavatkozásnál alkalmazott fájdalomcsillapítás fajtája, száma és előfordulása a be avatkozások arányában

\begin{tabular}{|c|c|c|c|c|}
\hline \multirow[t]{2}{*}{ Beavatkozás } & \multicolumn{3}{|c|}{$\begin{array}{c}\text { A fájdalomcsillapítások } \\
\text { száma }\end{array}$} & \multirow{2}{*}{$\begin{array}{l}\text { A fájdalom- } \\
\text { csillapítás mellett } \\
\text { végzett } \\
\text { beavatkozások } \\
\text { aránya (\%) }\end{array}$} \\
\hline & $\begin{array}{l}\text { Nem } \\
\text { gyógy- } \\
\text { szeres }\end{array}$ & $\begin{array}{l}\text { Gyógy- } \\
\text { szeres }\end{array}$ & $\begin{array}{l}\text { Kombi- } \\
\text { nált }\end{array}$ & \\
\hline Összes beavatkozás & 1703 & 2431 & 56 & 31,47 \\
\hline $\begin{array}{l}\text { Gyomorszonda } \\
\text { levezetése }\end{array}$ & 302 & 500 & 6 & 23,57 \\
\hline $\begin{array}{l}\text { Gyomorszonda } \\
\text { eltávolítása }\end{array}$ & 299 & 502 & 6 & 23,59 \\
\hline Ragasztó eltávolítása & 235 & 117 & 11 & 34,27 \\
\hline Sarokszúrás & 227 & 247 & 7 & 47,86 \\
\hline Vérvétel-vénaszúrás & 225 & 71 & 11 & 47,96 \\
\hline Nasalis szívás & 26 & 330 & 3 & 58,75 \\
\hline Branülszúrás & 129 & 16 & 3 & 36,36 \\
\hline Orrkanül behelyezése & 3 & 8 & 0 & 2,76 \\
\hline Branül eltávolítása & 84 & 12 & 1 & 27,79 \\
\hline Tubusszívás & 0 & 307 & 1 & 98,40 \\
\hline
\end{tabular}

összesen 65 beavatkozást szenvedtek el. Folyamatos gyógyszeres fájdalomcsillapításra intravénás nalbufint és fentanilt használtunk. Ez azonban a konvencionálisan lélegeztetett betegeinknél protokoll szerint használt fájdalomcsillapítás volt, nem pedig az egyes beavatkozásokhoz adott analgetikum. Az alkalmi gyógyszeres terápia többségében $(82 \%)$ a szemészeti vizsgálathoz alkalmazott fájdalomcsillapító szemcseppet, kisebb arányban a nem sürgősségi intubáláskor használt nalbufint jelentette. A nem gyógyszeres fájdalomcsillapítást tovább bontva, annak nagy része multiszenzoros stimuláció (44\%) és cumi $(40 \%)$ alkalmazása volt. Jóval kevesebbszer, de lefejt anyatej adása $(<1 \%)$, szoptatás $(<1 \%)$ és kenguruzás $(1,3 \%)$ közben is végeztünk beavatkozást. Ikrek esetében kihasználtuk a közös ápolás, a 'co-bedding' (14\%) fájdalomcsillapító hatását.

A leggyakoribb fájdalmas beavatkozások közül csaknem minden tubusszívásnál $(98,4 \%)$, a nasalis szívások 58,7\%-ánál, a sarokszúrások 47,8\%-ánál, a vénás vérvételek 47,9\%-ánál alkalmaztunk valamilyen analgetikus terápiát (4. táblázat).

A gestatiós kor és a születési súly függvényében vizsgálva, látványos a különbség a legkisebb születési súlyú és gestatiós korú csoport és a többi beteg között. Míg az előbbieknél a beavatkozások nagyobb része fájdalomcsillapítással történt, a többi csoportban ez az arány sajnos megfordult (2. ábra).

A fájdalomcsillapítást szignifikánsan többször alkalmaztuk (5. táblázat) az alacsonyabb gestatiós korú $(<0,001)$ és születési súlyú $(<0,001)$, valamint a lélegeztetett $(<0,001)$ betegeink esetében.

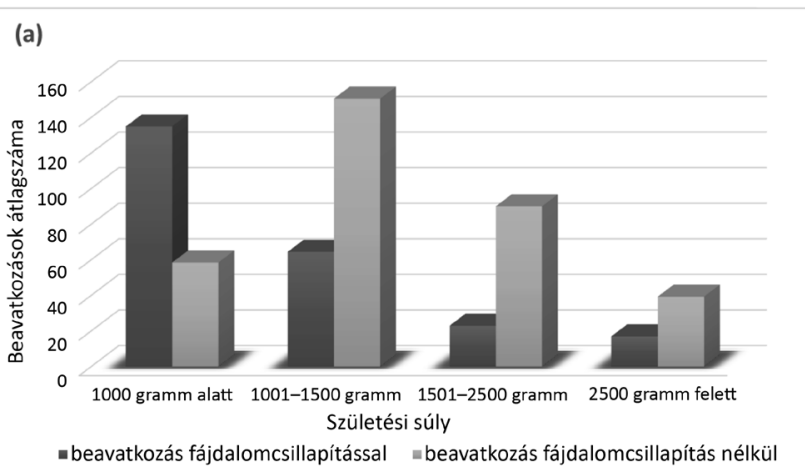

(b)

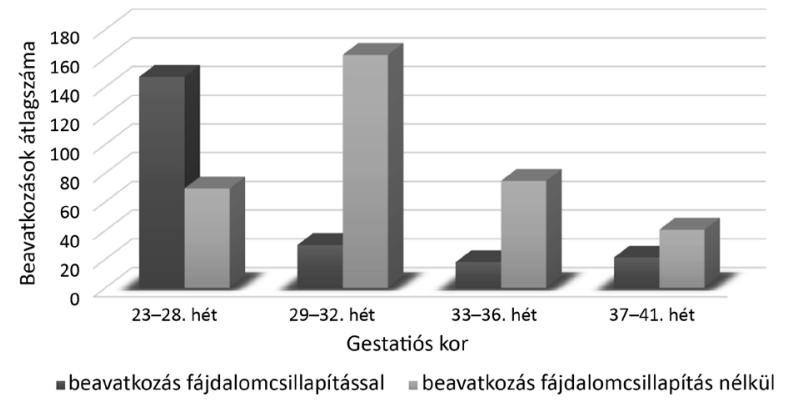

2. ábra

A hospitalizáció első 14 napján fájdalomcsillapítás mellett és fájdalomcsillapítás nélkül végzett fájdalmas beavatkozások átlag száma gyermekenként a születési súly (a) és a gestatiós kor (b) függvényében

\section{Megbeszélés}

Magyarországon az újszülöttek 8,5-9\%-a a 37. gestatiós hét előtt, koraszülöttként jön világra [1], mely európai viszonylatban magas arány [31]. Az ország NIC-eiben évente körülbelül 6000 koraszülöttet és beteg újszülöttet kezelnek.

Tudomásunk szerint ez az első olyan vizsgálat, amely egy hazai NIC-ben a fájdalmas beavatkozások számát, természetét és a hozzájuk kapcsolódó fájdalomcsillapítás alkalmazását vizsgálta.

Osztályunk az észak-magyarországi régió egyetlen tercier szintű neonatológiai központja, ahol évente 650700 beteg gyermek ellátása történik. A vizsgálati időszak 4 hónapjában 143 beteget kezeltünk, közülük a vizsgálatba mindenkit be tudtunk vonni. A 4 hónapos vizsgálati periódus lehetővé tette, hogy az ápolószemélyzet minden tagja részt vegyen a vizsgálatban, és csökkentette a mindennapi klinikai gyakorlatban a felmérés hatására bekövetkező átmeneti változtatások valószínűségét.

A vizsgált időszakban összesen 13314 fájdalmas beavatkozáson estek át a betegek. Átlagosan 93,1/gyermek és 8,2/nap/gyermek beavatkozást szenvedtek el, amelyek nagy részénél $(68,5 \%)$ nem történt fájdalomcsillapítás. A kettős csapás elmélete [17] vizsgálatunk szerint is igazolódott: a legkisebbeknek és legesendőbbeknek okoztunk a legnagyobb számban fájdalmat. A legtöbb beavatkozást az első 2 életnapon végeztük. Ez könnyen magyarázható, hiszen a kezdeti állapotstabilizáláshoz, 
5. táblázat |A fájdalmas beavatkozások száma, az alkalmazott fájdalomcsillapítás és a betegek egyes jellemzőinek kapcsolata

\begin{tabular}{|c|c|c|c|c|c|c|c|}
\hline & & $\begin{array}{l}\text { Medián (IQR) } \\
\text { beavatkozás/gyerek }\end{array}$ & $Z$ vagy $\chi^{2 *}$ & p-érték & $\begin{array}{l}\text { Medián (IQR) } \\
\text { fájd.csill./gyerek }\end{array}$ & $Z$ vagy $\chi^{2 *}$ & p-érték \\
\hline \multirow{4}{*}{$\begin{array}{l}\text { Gestatiós kor } \\
\text { (hét) }\end{array}$} & $23-28$ & $196,0(187,0-267,0)$ & \multirow[t]{4}{*}{50,317} & \multirow[t]{4}{*}{0,001} & $175,0(87,0-189,0)$ & \multirow[t]{4}{*}{27,62} & \multirow[t]{4}{*}{0,001} \\
\hline & $29-32$. & $174,0(149,0-245,0)$ & & & $18,0(7,5-48,5)$ & & \\
\hline & $33-36$ & $73,0(43,25-144,25)$ & & & $10,0(6,75-18)$ & & \\
\hline & $37-42$. & $38(24,0-68,0)$ & & & $8,0(5,0-13,0)$ & & \\
\hline \multirow[t]{4}{*}{ Születési súly (g) } & $\leq 1000$ & $187,0(174,0-196,0)$ & \multirow[t]{4}{*}{46,174} & \multirow[t]{4}{*}{0,001} & $175,0(32,0-189,0)$ & \multirow[t]{4}{*}{36,49} & \multirow[t]{4}{*}{0,001} \\
\hline & $1001-1500$ & $211,0(190,0-261,0)$ & & & $69,0(40,0-81,0)$ & & \\
\hline & $1501-2500$ & $82,5(44,75-163,5)$ & & & $9,0(7,0-16,75)$ & & \\
\hline & $>2500$ & $38,0(24,0-68,0)$ & & & $7,0(5,0-13,5)$ & & \\
\hline \multirow[t]{2}{*}{ Légzéstámogatás } & Igen & $153,0(76,0-206,0)$ & \multirow[t]{2}{*}{$-8,162$} & \multirow[t]{2}{*}{0,001} & $18,0(8,0-63,0)$ & \multirow[t]{2}{*}{$-5,082$} & \multirow[t]{2}{*}{0,001} \\
\hline & Nem & $35,0(23,0-52,0)$ & & & $7,0(5,0-11,0)$ & & \\
\hline
\end{tabular}

*A Z a Mann-Whitney U-teszt, a $\chi^{2}$ a Kruskal-Wallis-teszt során lett meghatározva

fájd.csill. = fájdalomcsillapítás; IQR = interkvartilis tartomány

a diagnózis felállításához, a terápia megkezdéséhez szükséges invazív beavatkozások nagy része ekkor történik. Ennek ismerete ugyanakkor potenciális lehetőséget is biztosít az első életnapok beavatkozásainak jobb tervezésére, csökkentésére.

Eredményeink összehasonlítása az azonos időtartamú külföldi kutatásokkal - a vizsgálat során mért fájdalmas beavatkozások különbözősége miatt - nem könnyú. Roofthooft és mtsai [24] Hollandiában naponta gyermekenként átlagosan 11,4, Carbajal és munkacsoportja 12 fájdalmas beavatkozást mért [25], Britto és mtsai [28] 101 beteg vizsgálatával átlagosan $8 /$ nap, míg egy délkoreai tanulmány [26] napi átlagban 7,5 fájdalmas eljárásról számolt be gyermekenként. Cruz és mtsai összefoglaló közleménye [22] naponta és gyermekenként átlagosan 7,5 és 17,3 közötti beavatkozásszámot közölt. A fájdalmas beavatkozások számát a gestatiós idő hossza is befolyásolhatja [28]. Vizsgálatunkban ez átlagosan 36,0 hét volt, hasonlóan a szintén alacsonyabb beavatkozási számot mérô Britto (35,1 hét) [28] és Jeong (35,4 hét) kutatásaihoz [26]. Ugyanakkor Roofthooft és Carbajal vizsgálatai esetében $[24,25]$ az átlagos gestatiós idő rövidebb $(33,0$, illetve 31,6 hét), a napi beavatkozási átlagszám pedig magasabb volt. A leggyakoribb beavatkozások Cruz [22] összefoglalója szerint nemzetiségtól függetlenül a sarok- és vénaszúrás, valamint a nasalis, oralis, trachealis leszívások voltak. Vizsgálatunkban szintén ezek fordultak elő a leggyakrabban, kiegészítve a gyomorszonda levezetésével és eltávolításával, valamint a ragasztószalag eltávolításával. Ez utóbbiak számos vizsgálat során szintén a 10 leggyakoribb beavatkozás között szerepeltek [24, 26-28, 32, 33]. A fájdalmas eljárások természetének ismerete lehetőséget teremt azok számának, illetve az általuk okozott fájdalom mértékének a csökkentésére. A sarokszúráshoz használt tú helyett speciális lándzsa alkalmazásával [34] és a ragasztószalag eltávolításához megfelelő oldat használatával $[35,36]$ egyszerú módszerekkel csökkenthető a fájdalom. A gyo- morszonda levezetésének és eltávolításának száma tartós szonda kiterjedtebb alkalmazásával mérsékelhető. A branülszúrások és vérvételek számát indokolt esetben CVC-k behelyezésével lehet csökkenteni.

A gestatiós idő rövidülésével és a születési súly csökkenésével párhuzamosan a beavatkozások számának emelkedését tapasztaltuk a 28. gestatiós hétig és 1000 gramm születési súlyig. Ezen értékek alatt azonban az első élethéten kismértékben alacsonyabb volt a beavatkozások száma (3. ábra). Lehetséges magyarázat eredményeinkre a legkisebb koraszülöttek ellátása során szigorúbban alkalmazott „minimal handling”, csak a legszükségesebb beavatkozások elvégzése. Sajnálatos, hogy a második élethéten ezt a csökkenést már nem észleltük. Ekkor a legkisebb gestatiós korú és a legkisebb születési súlyú koraszülötteknél mértük a legtöbb beavatkozást. A beavatkozások adott napon belüli megoszlását tekintve azt találtuk, hogy nem volt „fájdalommentes időszak” (egyik koraszülöttünk esetében 24 óra alatt 36 beavatkozást végeztünk). Minden napszakban történt beavatkozás, ami lehetetlenné teszi a növekedés és fejlődés szempontjából esszenciális nyugodt alvást. Az alvási időszakok gyakori megzavarása befolyásolja az agy fejlődését [37, 38], ezért kívánatos lenne, amennyire a beteg állapota megengedi, fájdalom- és beavatkozásmentes időszakok kijelölése, megtartása [39].

Fájdalomcsillapítás a beavatkozások 31,5\%-ában történt. Más vizsgálatokban ez nagyon széles skálán mozgott. Míg egy kínai tanulmány szerint [29] egyáltalán nem alkalmaztak analgesiát, addig egy kanadai multicentrikus vizsgálatban [32] részt vevő NIC-ben a szövetkárosító beavatkozások $90 \%$-át fájdalomcsillapítás mellett végezték. A jelen vizsgálatban összesen 4190 alkalommal alkalmaztuk az analgesia valamilyen formáját. Ennek 55,5\%-a nem kifejezetten a beavatkozás miatt alkalmazott fájdalomcsillapítás, hanem a gépi lélegeztetés miatt használt intravénás opioidterápia volt. Vizsgálatok igazolták, hogy koraszülöttek esetében az invazív 
(a)

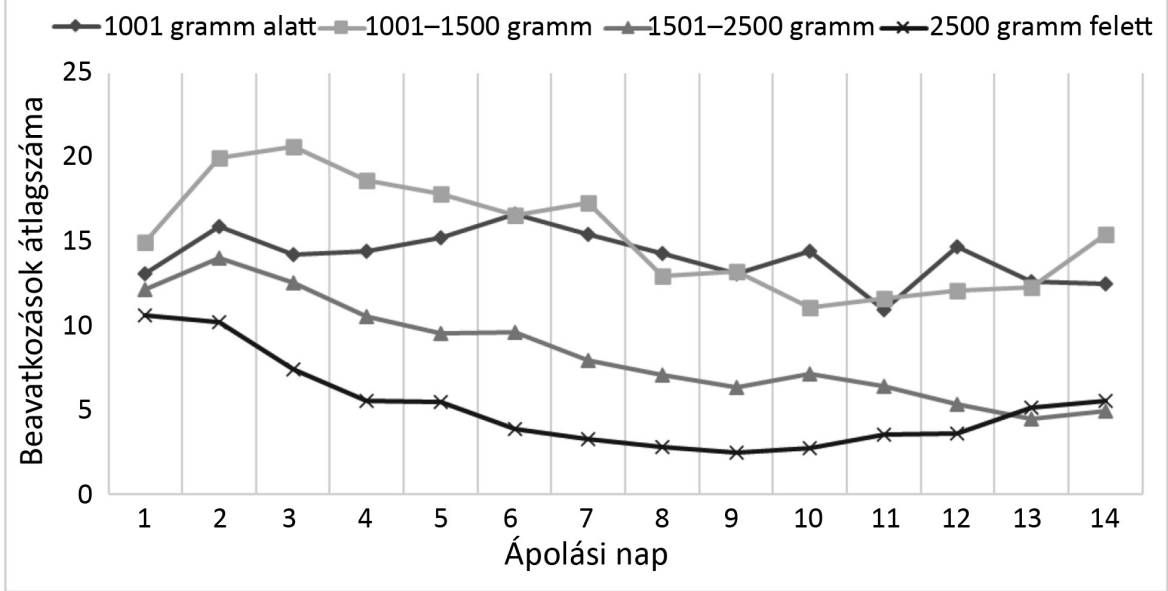

(b)

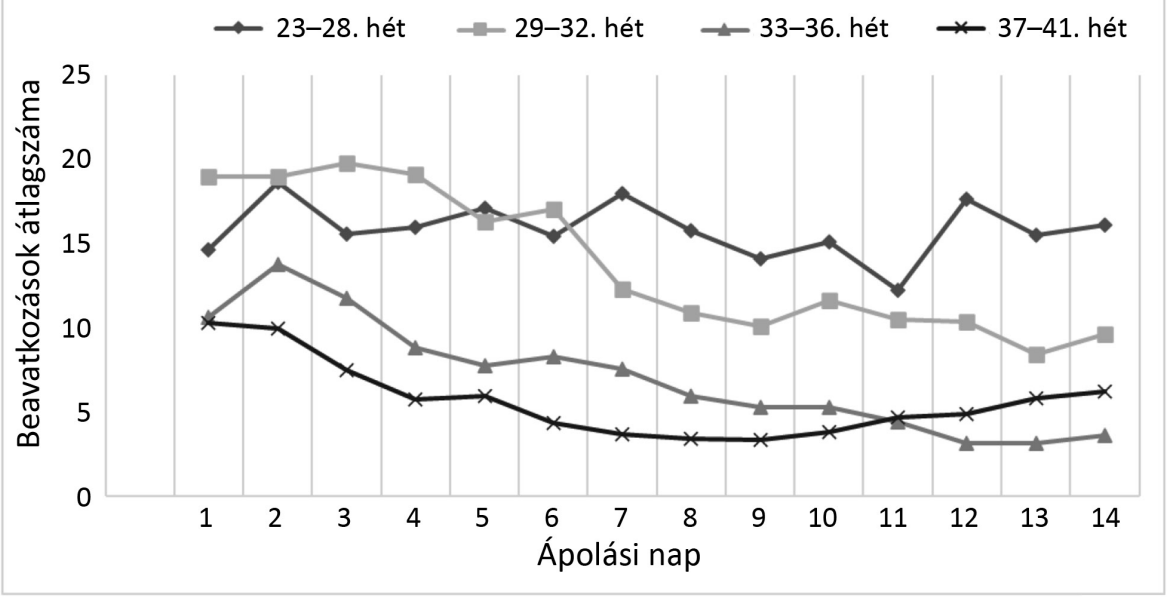

3. ábra

| A fájdalmas beavatkozások napi átlagszáma a születési súly (a) és a gestatiós kor (b) függvényében a hospitalizáció első 14 napján

beavatkozás által okozott akut fájdalom csillapítására az egyéb okból folyamatosan adagolt morfin nem hatékony. Ezekben az esetekben egyéb, célzottan a beavatkozáshoz adott analgetikum alkalmazása szükséges [40, 4l]. A vizsgálat során mindössze a fájdalomcsillapítások $1,3 \%$-a volt kombinált terápia, intravénás nalbufin mellett nem gyógyszeres fájdalomcsillapítási módszer alkalmazása. Hasonló eredménye volt Carbajal és mtsai [25] kutatásának. Eszerint a folyamatosan adagolt analgetikum mellett a beavatkozásokhoz a klinikusok kevesebb célzott fájdalomcsillapítást alkalmaztak. Ennek ismeretében a lélegeztetett és folyamatos opioidterápiában részesülő koraszülötteknél a beavatkozások fájdalmának csillapítására fokozott figyelmet kell fordítani. A szülők bevonásával végzett nem gyógyszeres fájdalomcsillapító módszerek (szoptatás, kenguruzás) igazolt hatékonysága [42-45] ellenére vizsgálatunkban alacsony volt ezen módszerek alkalmazása is (szoptatás <1\%, kenguruzás 1,3\%). Egy Kanadában végzett vizsgálat szerint [32] a szülők jelenléte egyértelmúen pozitívan befolyásolta a fájdalomcsillapítás alkalmazását. Ezért a szülőket nemcsak engedni, de bátorítani kell, hogy legyenek jelen gyermekük mellett. A legszélesebb körben vizsgált nem gyógyszeres fájdalomcsillapítási lehetôség a szacharóz- és glükózoldat. Használatukkal komoly mellékhatások nélkül, hatékonyan csökkenthetjük a beavatkozásokhoz kapcsolódó fájdalmat mind érett újszülöttek, mind koraszülöttek esetében $[46,47]$. A világ számos országában írásos protokollok szerint történik a fájdalom kezelése a NIC-ekben. Ennek megléte is növelheti a fájdalomcsillapító módszerek alkalmazásának számát [48]. A fájdalom kezelése nemcsak annak csillapítását jelenti, hanem felismerését, észlelését, mértékének becslését is. Ehhez minden újszülött intenzív osztálynak javasolt többféle, a különböző betegcsoportok (koraszülött, újszülött) és különböző típusú fájdalom (akut, krónikus, posztoperatív) mérésére alkalmas fájdalommérési módszer használata $[49-51]$.

A jelen vizsgálatnak vannak korlátai. Először: a beavatkozások és a fájdalomcsillapítási módszerek lejegyzésé- 
nek pontosságában. Az adatgyưjtést rendszeresen ellenőriztük, a kérdőíven rögzített adatokat naponta összevetettük az egészségügyi dokumentációval, majd utólag duplán ellenőriztük. Ennek ellenére nem garantálható biztosan, hogy minden fájdalmas beavatkozás és fájdalomcsillapítás feljegyzésre került. Másodszor: az adatgyưjtés a kórházi kezelés első 2 hetében történt, és nem annak teljes időtartama alatt. Harmadszor: a kérdo”íven nem szereplő, az ápolószemélyzet által utólag hozzáadott beavatkozások fájdalmasságának megítélése szubjektív módon, az egészségügyi személyzet megfigyelőképességén alapult. Nem használtunk validált fájdalomskálát, amely objektívebbé tehette volna a vizsgálatot. Negyedszer: a kutatást egyetlen NIC-ben végeztük, így eredményeinkből az ország többi újszülött intenzív osztályára vonatkozó következtetést nem tudunk levonni.

Mindezek ellenére a kutatás során a fájdalmas beavatkozások számának fontos csökkentési lehetőségeit és a nem gyógyszeres fájdalomcsillapítási módszerek kiterjedtebb alkalmazásának szükségességét tártuk fel. A vizsgálat könnyen reprodukálható. Más koraszülöttosztályokon is egyszerúen elvégezhető, az adott osztályra szabott fájdalomcsillapítási protokoll kidolgozása, illetve átdolgozása előtt. Meghatározott időközönként való megismétlésével pedig nemcsak a protokoll betartását és fájdalomkezelésünket ellenőrizhetjük, de ismételten felhívhatjuk a figyelmet a fájdalommegelőzés és -csillapítás fontosságára és az ellátószemélyzet képzésének szükségességére.

\section{Következtetés}

A jelen vizsgálat során egy hazai NIC-ben határoztuk meg a kezelt betegek által elszenvedett fájdalmas beavatkozások számát és a kapcsolódó fájdalomcsillapítási lehetőségeket. A vizsgálatot a kórházi kezelés első 14 napján végeztük. A vizsgált időszakban összesen 13314 fájdalmas beavatkozás történt, gyermekenként átlagosan 93,1, naponta és gyermekenként átlagosan 8,2. Fájdalomcsillapítást összesen 4190 alkalommal, a beavatkozások 31,5\%-ában végeztünk. Az alacsonyabb gestatiós korú és születési súlyú, légzéstámogatást igénylő újszülöttek, koraszülöttek szenvedték el a legtöbb beavatkozást. Viszont ugyanezen csoportoknál a fájdalomcsillapítók alkalmazása is kiterjedtebb volt. Ismerve az ismétlődő, kezeletlen fájdalom hosszú távú hatásait, jobb fájdalommenedzsment alkalmazása lenne szükséges. Kutatásunk rávilágít a tudományos bizonyítékokkal alátámasztott kívánatos és a mindennapi gyakorlatban alkalmazott fájdalomkezelés közötti diszkrepanciára. A beavatkozások tervezésével, összehangolásával, a szükségtelen eljárások elhagyásával, a nem gyógyszeres fájdalomcsillapítási lehetőségek kiterjedtebb alkalmazásával, írásos fájdalomkezelési protokoll használatával, a fájdalom mérésével javítani lehetne eredményeinken.
Anyagi támogatás: A kézirat megírásáért és a kapcsolódó kutatómunkáért a szerzők anyagi támogatásban nem részesültek.

Szerzôi munkamegosztás: I. J.: A kutatás ötlete, irodalomkutatás, az adatok feldolgozása, statisztikai számítások végzése, a cikk megírása. F. M., F. D., K. M., M. T., V. K., Sz. I.: Adatgyưjtés, irodalomkutatás. A cikk végleges változatát valamennyi szerző elolvasta és jóváhagyta.

Érdekeltségek: A szerzőknek nincsenek érdekeltségeik.

\section{Köszönetnyilvánítás}

A szerzők köszönetüket fejezik ki a Borsod-Abaúj-Zemplén Megyei Központi Kórház Újszülött Intenzív Osztálya ápolónőinek az adatgyújtésben végzett munkájukért.

\section{Irodalom}

[1] Hungarian Central Statistical Office. Infant mortality. [Központi Statisztikai Hivatal. Csecsemőhalálozás.] KSH, Statisztikai tükör, Budapest, 2019. február 22. Available from: http://www.ksh. hu/docs/hun/xftp/stattukor/csecsemohalalozas.pdf [accessed: May 15, 2021]. [Hungarian]

[2] Brennan F, Lohman D, Gwyther L. Access to pain management as a human right. Am J Public Health 2019; 109: 61-65.

[3] Anand KJ, Hickey PR. Pain and its effects in the human neonate and fetus. N Engl J Med. 1987; 317: 1321-1329.

[4] Anand KJ, Carr DB. The neuroanatomy, neurophysiology and neurochemistry of pain, stress, and analgesia in newborns and children. Pediatr Clin North Am. 1989; 36: 795-822.

[5] Giannakoulopoulos X, Sepulveda W, Kourtis P, et al. Fetal plas$\mathrm{ma}$ cortisol and beta-endorphin response to intrauterine needling. Lancet 1994; 344: 77-81.

[6] Slater R, Cantarella A, Gallella S, et al. Cortical pain responses in human infants. J Neurosci. 2006; 26: 3662-3666.

[7] Hatfield LA. Neonatal pain: what's age got to do with it? Surg Neurol Int. 2014; 5(Suppl 13): S479-S489.

[8] Grunau RE, Holsti L, Peters JW. Long-term consequences of pain in human neonates. Semin Fetal Neonatal Med. 2006; 11: $268-275$.

[9] Williams MD, Lascelles BD. Early neonatal pain - a review of clinical and experimental implications on painful conditions later in life. Front Pediatr. 2020; 8: 30.

[10] Grunau RE. Neonatal pain in very preterm infants: long-term effects on brain, neurodevelopment and pain reactivity. Rambam Maimonides Med J. 2013; 4: e0025.

[11] Brummelte S, Chau CM, Cepeda IL, et al. Cortisol levels in former preterm children at school age are predicted by neonatal procedural pain-related stress. Psychoneuroendocrinology 2015; 51: 151-163.

[12] Duerden EG, Grunau RE, Guo T, et al. Early procedural pain is associated with regionally-specific alterations in thalamic development in preterm neonates. J Neurosci. 2018; 38: 878-886.

[13] McPherson C, Miller SP, El-Dib M. The influence of pain, agitation, and their management on the immature brain. Pediatr Res. 2020; 88: 168-175.

[14] Walker SM. Long-term effects of neonatal pain. Semin Fetal Neonatal Med. 2019; 24: 101005

[15] Gharavi B, Schott C, Nelle M, et al. Pain management and the effect of guidelines in neonatal units in Austria, Germany and Switzerland. Pediatr Int. 2007; 49: 652-658.

[16] Lago P, Garetti E, Merazzi D, et al. Guidelines for procedural pain in the newborn. Acta Paediatr. 2009; 98: 932-939. 
[17] American Academy of Pediatrics Committee on Fetus and Newborn, American Academy of Pediatrics Section on Surgery, Canadian Paediatric Society Fetus and Newborn Committee. Prevention and management of pain in the neonate: an update. Pediatrics 2006; 118: 2231-2241.

[18] Anand KJ, International Evidence-Based Group for Neonatal Pain. Consensus statement for the prevention and management of pain in the newborn. Arch Pediatr Adolesc Med. 2001; 155: 173-180.

[19] Roué JM, Kuhn P, Lopez Maestro M, et al. Eight principles for patient-centred and family-centred care for newborns in the neonatal intensive care unit. Arch Dis Child Fetal Neonatal Ed. 2017; 102: F364-F368.

[20] Walker SM. Management of procedural pain in NICUs remains problematic. Paediatr Anaesth. 2005; 15: 909-912.

[21] Cignacco E, Hamers JP, Stoffel L, et al. Routine procedures in NICUs: factors influencing pain assessment and ranking by pain intensity. Swiss Med Wkly. 2008; 138: 484-491. [Erratum: Swiss Med Wkly. 2009; 139: 32.]

[22] Cruz MD, Fernandes AM, Oliveira CR. Epidemiology of painful procedures performed in neonates: a systematic review of observational studies. Eur J Pain 2016; 20: 489-498.

[23] Orovec A, Disher T, Caddell K, et al. Assessment and management of procedural pain during the entire neonatal intensive care unit hospitalization. Pain Manag Nurs. 2019; 20: 503-511.

[24] Roofthooft DW, Simons SH, Anand KJ, et al. Eight years later are we still hurting newborn infants? Neonatology 2014; 105: 218-226.

[25] Carbajal R, Rousset A, Danan C, et al. Epidemiology and treatment of painful procedures in neonates in intensive care units. JAMA 2008; 300: 60-70

[26] Jeong IS, Park SM, Lee JM, et al. The frequency of painful procedures in neonatal intensive care units in South Korea. Int J Nurs Pract. 2014; 20: 398-407.

[27] Cignacco E, Hamers J, van Lingen RA, et al. Neonatal procedural pain exposure and pain management in ventilated preterm infants during the first 14 days of life. Swiss Med Wkly. 2009; 139: 226-232.

[28] Britto CD, Rao Pn S, Nesargi S, et al. PAIN - perception and assessment of painful procedures in the NICU. J Trop Pediatr. 2014; 60: 422-427.

[29] Chen M, Shi X, Chen Y, et al. A prospective study of pain experience in a neonatal intensive care unit of China. Clin J Pain 2012; 28: 700-704.

[30] Kassab M, Alhassan AA, Alzoubi KH, et al. Number and frequency of routinely applied painful procedures in university neonatal intensive care unit. Clin Nurs Res. 2019; 28: 488-501.

[31] Zeitlin J, Szamotulska K, Drewniak N, et al. Preterm birth time trends in Europe: a study of 19 countries. BJOG 2013; 120: 1356-1365

[32] Johnston C, Barrington KJ, Taddio A. Pain in Canadian NICUs: have we improved over the past 12 years? Clin J Pain 2011; 27: 225-232.

[33] Orovec A, Disher T, Caddell K, et al. Assessment and management of procedural pain during the entire neonatal intensive care unit hospitalization. Pain Manag Nurs. 2019; 20: 503-511.
[34] Goto T, Inoue T, Kamiya C, et al. Neonatal pain response to automatic lancet versus needle heel-prick blood sampling: a prospective randomized controlled clinical trial. Pediatr Int. 2020; 62: 357-362.

[35] Collier M. Minimising pain and medical adhesive related skin injuries in vulnerable patients. Br J Nurs. 2019; 28: S26-S32.

[36] Denyer J. Reducing pain during the removal of adhesive and adherent products. Br J Nurs. 2011; 20: S28, S30-S35.

[37] Morrissey MJ, Duntley SP, Anch AM, et al. Active sleep and its role in the prevention of apoptosis in the developing brain. Med Hypotheses 2004; 62: 876-879.

[38] Peirano PD, Algarín CR. Sleep in brain development. Biol Res. 2017; 40: 471-478.

[39] Bertelle V, Sevestre A, Laou-Hap K, et al. Sleep in the neonatal intensive care unit. J Perinat Neonatal Nurs. 2007; 21: 140-148.

[40] Simons SH, van Dijk M, van Lingen RA, et al. Routine morphine infusion in preterm newborns who received ventilatory support: a randomized controlled trial. JAMA 2003; 290: 2419-2427.

[41] Carbajal R, Lenclen R, Jugie M, et al. Morphine does not provide adequate analgesia for acute procedural pain among preterm neonates. Pediatrics 2005; 115: 1494-1500.

[42] McNair C, Campbell-Yeo M, Johnston C, et al. Non-pharmacologic management of pain during common needle puncture procedures in infants: current research evidence and practical considerations: an update. Clin Perinatol. 2019; 46: 709-730.

[43] Hatfield LA, Murphy N, Karp K, et al. A systematic review of behavioral and environmental interventions for procedural pain management in preterm infants. J Pediatr Nurs. 2019; 44: 2230 .

[44] Mangat AK, Oei JL, Chen K, et al. A review of non-pharmacological treatments for pain management in newborn infants. Children 2018; 5 : 130 .

[45] Pillai Riddell RR, Racine NM, Gennis HG, et al. Non-pharmacological management of infant and young child procedural pain. Cochrane Database Syst Rev. 2015; 12: CD006275.

[46] Stevens B, Yamada J, Ohlsson A, et al. Sucrose for analgesia in newborn infants undergoing painful procedures. Cochrane Database Syst Rev. 2016; 7: CD001069

[47] Bueno M, Yamada J, Harrison D, et al. A systematic review and meta-analyses of nonsucrose sweet solutions for pain relief in neonates. Pain Res Manag. 2013; 18: 153-161.

[48] Lago P, Guadagni A, Merazzi D, et al. Pain management in the neonatal intensive care unit: a national survey in Italy. Paediatr Anaesth. 2005; 15: 925-931.

[49] Anand KJ, Eriksson M, Boyle EM, et al. Assessment of continuous pain in newborns admitted to NICUs in 18 European countries. Acta Paediatr. 2017; 106: 1248-1259.

[50] Maxwell LG, Fraga MV, Malavolta CP. Assessment of pain in the newborn: an update. Clin Perinatol. 2019; 46: 693-707.

[51] Relland LM, Gehred A, Maitre NL. Behavioral and physiological signs for pain assessment in preterm and term neonates during a nociception-specific response: a systematic review. Pediatr Neurol. 2019; 90: 13-23.

(Ivancsó Johanna dr., Miskolc, Szentpéteri kapu 72-76., 3526 e-mail: johannaivancso@gmail.com)

A cikk a Creative Commons Attribution 4.0 International License (https://creativecommons.org/licenses/by/4.0/) feltételei szerint publikált Open Access közlemény, melynek szellemében a cikk bármilyen médiumban szabadon felhasználható, megosztható és újraközölhetö, feltéve, hogy az eredeti szerző és a közlés helye, illetve a CC License linkje és az esetlegesen végrehajtott módosítások feltüntetésre kerülnek. (SID_1) 